\title{
Dziewiętnastowieczne edycje literatury staropolskiej a światopogląd polskiego modernizmu. Rekonesans
}

Badając wnikliwie stosunek Młodej Polski do twórczości Jana Kochanowskiego, Andrzej Z. Makowiecki wskazał niegdyś na istnienie dwóch typów „,recepcji twórczości jakiegokolwiek pisarza w epokach literackich następujących po tej, do której został on przez historię literatury i chronologię przypisany"1.

Płaszczyzna pierwsza, recepcji wyrazistej i łatwej do opisu, dotyczy faktów recepcyjnych. Należą do nich obchody rocznicowe i inne objawy kultu, jak muzea i pomniki, artykuły prasowe i naukowe monografie, przyczynki i wzmianki, wznowienia dzieł i wystawienia teatralne, okazjonalne przywołania, dedykacje, cytaty i kryptocytaty itp. Ta recepcja, poświadczona faktami, odnosi się bardziej do historii literatury niż do literatury samej, bywa też często powierzchowna. Na płaszczyźnie drugiej ujawniają się problemy znacznie bliższe samej literaturze, mniej oczywiste fakty recepcyjne dotyczące sfery świadomości kulturowej i literackiej. Warstwa ta, o wiele mniej wyrazista dla faktografa, dotyczy oddziaływania pisarza w późniejszych epokach jako modelu osobowości twórczej, postawy światopoglądowej, pojmowania statusu artysty, reprezentanta orientacji literackiej lub prądu, mającego sprzyjające warunki do odnowienia się w kulturze. W tej sferze recepcji realizują się inspiracje nieporównanie głębsze niż te, które wyrazić można liczbą wznowień i artykułów².

Trudno oczywiście podważać najogólniejszą zasadę tego ujęcia, ów rejestr możliwych sposobów uobecnienia tradycji literackiej w epokach późniejszych oraz ich podział na poddające się faktografii łatwiej lub trudniej. Wątpliwości może budzić jednak potraktowanie w takich samych kategoriach, jako recepcji

\footnotetext{
* Dr, m.m.kacprzak@uw.edu.pl, Uniwersytet Warszawski, Biblioteka Uniwersytecka w Warszawie, Gabinet Zbiorów XIX wieku, ul. Dobra 56/66, 00-312 Warszawa.

${ }^{1}$ A.Z. Makowiecki, Młoda Polska wobec tradycji czarnoleskiej, w: Jan Kochanowski 1584-1984. Epoka - Twórczość - Recepcja, red. J. Pelc, P. Buchwald-Pelcowa i B. Otwinowska, t. 2, Wydawnictwo Lubelskie, Lublin 1989, s. 331.

${ }^{2}$ Tamże.
} 
„często powierzchownej”, takich faktów jak z jednej strony „obchody rocznicowe i inne objawy kultu” czy „okazjonalne przywołania”, a z drugiej - naukowe opracowania historycznoliterackie i edytorstwo dzieł literackich (,naukowe monografie”, „wznowienia dzieł”). Różnica jest bowiem z punktu widzenia badacza literatury i życia literackiego bardzo istotna: o ile różne „objawy kultu”, związane na przykład z obchodami rocznic (tak ważnymi w kulturze drugiej połowy XIX wieku), ze swej istoty mają charakter silnie emocjonalny i niejako „pozamerytoryczny”, niekoniecznie wiążą się z faktyczną znajomością twórczości otaczanego kultem pisarza i opierają się niekiedy na wyobrażeniach stereotypowych czy ogólnikowych, o tyle przede wszystkim fakty z dziedziny edytorstwa (o szerszym adresie czytelniczym niż opracowania naukowe) oznaczają rzeczywistą recepcję tekstu dzieła literackiego. I dopiero edycje mogą stać się właściwym punktem wyjścia dla „faktów recepcyjnych dotyczących sfery świadomości kulturowej i literackiej”, owych ,głębszych inspiracji” - oddziaływania pisarzy dawniejszych na model osobowości twórczej, postawy światopoglądowe, pojmowanie statusu artysty w późniejszych epokach. Oddziaływania faktycznego i pełnego, bo opartego na rzeczywistej znajomości tekstów i poglądów, a nie pozornego, wynikającego z operowania sądami obiegowymi, mitami czy stereotypami. Gdy Makowiecki stwierdza, że „,przy tak zarysowanej hierarchii recepcji nie da się pominąc objawów oddziaływania na obu tych płaszczyznach"3 (i że badając miejsce Kochanowskiego w epoce Młodej Polski, „zarówno w jednej, jak i w drugiej rubryce «konta recepcyjnego» dostrzec można objawy ważkie"), konstatuje możliwe współwystępowanie dwóch typów recepcji, nie wskazuje jednak powiązań między nimi i - jak się zdaje - traktuje, wraz z całą recepcją pierwszego typu, edytorstwo tekstów literackich jako niższe w hierarchii w stosunku do owej recepcji w sferze świadomości czy światopoglądu. Można się zgodzić na taki sposób ujęcia o tyle tylko, o ile owa hierarchia dotyczy pierwszeństwa chronologicznego i logicznego, a nie wartości i znaczenia. Jeśli bowiem chodzi o relację między epokami tak odległymi jak staropolska i młodopolska - gdy odległość czasowa uniemożliwia powszechne korzystanie w codziennej lekturze $\mathrm{z}$ autentycznych lub bliskich autentycznym wydań utworów literackich (tak jak definiuje autentyczność teoria edytorstwa) - bez recepcji w zakresie edytorstwa dawnych tekstów nie może być pełnej recepcji w zakresie światopoglądu. (Oczywiście recepcja $\mathrm{w}$ zakresie światopoglądu może, niejako zwrotnie, zintensyfikować recepcję w zakresie edytorstwa). Udostępnienie i upowszechnienie tekstów - edytorstwo tekstów literackich - poprzedza i warunkuje ich zrozumienie oraz ewentualne przyjęcie ich przesłania, włączenie zawartej w nich wizji świata w światopogląd kolejnej epoki.

\footnotetext{
${ }^{3}$ Tamże.

${ }^{4}$ Tamże.
} 
Niniejszy szkic to głos upominający się o potraktowanie edycji dzieł literackich w epokach późniejszych niż te, w których powstały, jako ważnego typu recepcji tradycji literackiej, o ich powiązanie w badaniach z recepcją w zakresie światopoglądu, o uwzględnienie zależności przyczynowo-skutkowej między tym drugim, ciekawszym rzec można, typem recepcji a edytorstwem właśnie.

Zmierzając do rozpoznania paradygmatu modernistycznego, jego składowych, wyznaczników, inspiracji i przemian, proponujemy skierowanie uwagi badawczej także w stronę znaczenia dziewiętnastowiecznych edycji literatury staropolskiej dla kształtowania się światopoglądu (czy światopoglądów) polskiego modernizmu. Lata 1890-1918 są bowiem czasem intensywnej kontynuacji wszczętych już na progu XIX w. prac nad wydawaniem zabytków piśmienniczych polskiej kultury dawnej, silnego rozwoju polskiego edytorstwa dzieł literackich oraz wskazywania jego zadań i celów, poszukiwań warsztatowych i ideowych, wypracowywania zasad, coraz szerszego udostępniania nowych edycji tekstów staropolskich.

Po zaniedbaniach w ruchu wydawniczym XVII i pierwszej połowy XVIII w. oraz po oświeceniowym ożywieniu tej działalności, związanym przede wszystkim z osobą Franciszka Bohomolca, już od pierwszych dziesięcioleci XIX stulecia pojawiło się wiele inicjatyw, mających na celu udostępnienie Polakom dorobku staropolskiego piśmiennictwa. Przyświecały tym działaniom trzy cele: zapoznanie z przeszłością ojczyzny, jej językiem i kulturą sprzed okresu niewoli; ocalenie od zniszczenia i zapomnienia tekstów, zachowanych w rzadkich czy unikatowych starodrukach i rękopisach; dostarczenie wiarygodnych materiałów do badań naukowych nad polską przeszłością. Wszystkie te aspekty podporządkowane były celowi nadrzędnemu - uwarunkowanemu polityczno-społecznymi okolicznościami, eksponowaniu narodowej tradycji i tożsamości. Cel ten przyświecał stale edycjom różnym formalnie, bardziej lub mniej popularnym, bibliofilskim czy krytycznym. Równocześnie stopniowo kształtował się warsztat edytorski i związany z nim naukowy, krok po kroku zmierzający do ustalenia nowoczesnych wymagań co do podstawy wydania, sposobu prezentowania tekstu w transkrypcji, aparatu naukowego, komentarza edytorskiego. Przekonanie o silnej potrzebie dostarczenia polskiemu społeczeństwu jak najszybciej jak największej liczby tekstów prezentujących kulturę staropolską skutkowało ujmowaniem działań i ich efektów w serie wydawnicze i duże antologie, jak: „Wybór Celniejszych Pisarzów Polskich” Tadeusza Mostowskiego (Warszawa 1803-1805, 27 tomów, m.in. staropolskich); „Zbiór Pisarzów Polskich" spółki Antoniego Gałęzowskiego (Warszawa 1827-1837, 19 tomów); „Biblioteka Kieszonkowa Klasyków Polskich” Jana Nepomucena Bobrowicza (Lipsk 1835-1853, 40 tomów); „Pomniki do Historii Obyczajów w Polsce z XVI i XVII Wieku Wydane z Rzadkich Druków" Józefa Ignacego Kraszewskiego (Warszawa 1843); „Biblioteka Starożytna Pisarzy Polskich” Kazimierza Władysława Wójcickiego (Warszawa 1843-1844, 6 tomów); „Piśmiennictwo 
Polskie od Czasów Najdawniejszych aż do r. 1830" Wacława Aleksandra Maciejowskiego (Warszawa 1853, 4 tomy); „Biblioteka Polska” Kazimierza Józefa Turowskiego (Przemyśl-Sanok-Kraków 1855-1862, ok. 380 tomów); „Monumenta Poloniae Historica" Augusta Bielowskiego, a następnie Akademii Umiejętności w Krakowie (Lwów 1864-1897, 6 tomów); „Biblioteka Najcelniejszych Utworów Literatury Europejskiej" Salomona Lewentala i Piotra Chmielowskiego (Warszawa 1877-1900, ponad 100 tomów, m.in. staropolskich); „Biblioteka Zapomnianych Poetów i Prozaików Polskich XVI-XVIII wieku” Teodora Wierzbowskiego (Warszawa 1886-1908, 25 tomów); „Corpus Antiquissimorum Poetarum Poloniae Latinorum usque ad Ioannem Cochanovium" Akademii Umiejętności w Krakowie (Kraków, od 1887); „Biblioteka Pisarzów Polskich” Akademii Umiejętności w Krakowie (Kraków, od 1889 roku, 73 tomy do 1918 roku); „Pomniki Piśmiennictwa Polskiego” (Petersburg 1895); „Materiały k’ Istorii Russkogo Gosudarstwa XVI i XVII Stoleti” Teodora Wierzbowskiego (Warszawa 1896-1900, 3 tomy, m.in. z tekstami staropolskimi); „Biblioteka Dzieł Wyborowych” (Warszawa, od 1897 roku); „Materiały do Dziejów Piśmiennictwa Polskiego i Biografii Pisarzów Polskich” Teodora Wierzbowskiego (Warszawa 1900-1904, 2 tomy); „Arcydzieła Polskich i Obcych Pisarzy" Feliksa Westa (Brody, od 1902 roku, ok. 100 tomów, m.in. staropolskich); „Biblioteka Uniwersytetów Ludowych i Młodzieży Szkolnej” oraz „Wybór Pisarzów Polskich dla Domu i Szkoły” Gebethnera i Wolffa (Warszawa, od 1905 roku, m.in. teksty staropolskie); „Zabytki Piśmiennictwa Polskiego” (Lwów, od 1907 roku); „Białe Kruki” Józefa Kallenbacha i Karola Badeckiego (Lwów, od 1910 roku); „Biblioteka Klasyków Polskich” Konrada Drzewieckiego i Andrzeja Boleskiego (Warszawa, od 1914 roku). Równocześnie wielu kolekcjonerów i badaczy wydawało utwory staropolskie, nie ujmując swych prac w serie; do najważniejszych należą edycje faksymilowane: Adama Pilińskiego, związane z mecenatem Działyńskich (na przykład Kórnik-Paryż, 1861, 1876), Józefa Przyborowskiego i jego dzieci (Warszawa, 1881-1883), Władysława Bartynowskiego (Kraków 1883-1885). Kamieniem milowym w historii polskiego edytorstwa naukowego okazało się tak zwane Wydanie Pomnikowe dzieł Jana Kochanowskiego (Warszawa 1884), edycja krytyczna związana z obchodami trzechsetnej rocznicy śmierci Jana Kochanowskiego, owoc pracy zespołu wybitnych filologów i historyków. W tym samym 1884 roku odbył się w Krakowie pierwszy Zjazd historyczno-literacki im. Jana Kochanowskiego, poświęcony nie tyle badaniom nad twórczością czarnoleską, co diagnozie stanu historii literatury polskiej i postulatom prac badawczych i edytorskich z nią związanych; do najważniejszych jego momentów należał edytorsko-metodologiczny referat Romana Pilata Jak należy wydawać dzieła polskich pisarzów XVI $i$ XVII w.? oraz wstępny projekt Władysława Wisłockiego O podjęciu wydawnictwa Biblioteki Pisarzów 
Polskich . Efektem zjazdu w zakresie pogłębienia działalności i ożywienia prac edytorskich było później zainicjowanie przez krakowską Akademię Umiejętności nowoczesnej „Biblioteki Pisarzów Polskich”, której znaczenia dla praktyki, teorii edycji i refleksji historycznoliterackiej jeszcze w XX w. nie można przecenić, spopularyzowała bowiem literaturę dawną, udostępniając ją w poprawnej, choć przystępnej formie badaczom, studentom i laikom.

W wyniku tych licznych i różnorodnych działań wydawniczych w epoce Młodej Polski stosunkowo łatwo można było zapoznać się z dużą częścią twórczości ważnych pisarzy staropolskich: Galla Anonima, Jana Długosza, autorów średniowiecznej poezji religijnej i świeckiej, kazań i kronik, Jana Kochanowskiego, Mikołaja Reja, Biernata z Lublina, Andrzeja Krzyckiego, Łukasza Górnickiego, Marcina Bielskiego, Stanisława Orzechowskiego, Piotra Skargi, Macieja Kazimierza Sarbiewskiego, Wacława Potockiego, Wespazjana Kochowskiego, Jana Chryzostoma Paska, Andrzeja i Piotra Zbylitowskich, Jana Żabczyca, autorów komedii rybałtowskiej. Część tekstów udostępniono w pierwszej połowie XIX wieku, liczne pojawiły się w obiegu w latach osiemdziesiątych, ale wiele wydawano w latach 1890-1918 w edycjach krytycznych lub popularnych, wciąż zwracając uwagę na bogactwo dziedzictwa kultury polskiej.

Warto zapytać, czy intensywny rozwój edytorstwa dzieł staropolskich to zjawisko tylko współwystępujące $\mathrm{z}$ modernizmem w polskiej literaturze, czy też z nim związane, a zwłaszcza - czy wprowadzanie w obieg czytelniczy i świadomość społeczną tekstów staropolskich mogło powodować w Polsce końca wieku XIX przemiany światopoglądu. Jest to kierunek właściwie nieobecny zarówno w badaniach nad recepcją literatury staropolskiej, jak i nad literaturą i kulturą polską lat 1890-1918. Przyczyn tej nieobecności można szukać w kilku przekonaniach, często przyjmowanych w badaniach historycznoliterackich.

Pierwsze z nich to teza o odmienności formacji literaturoznawczej i literackiej oraz odrębności praktyki literaturoznawczej i literackiej w poszczególnych

${ }^{5}$ Zob. Pamiętnik zjazdu historyczno-literackiego imienia Jana Kochanowskiego, „Archiwum do dziejów literatury i oświaty w Polsce, wydawane przez komisję do badań tego zakresu przez Wydział Filologiczny Akademii Umiejętności w Krakowie powołaną", t. V, Kraków 1886, s. 97-114.

${ }^{6}$ Por. J. Starnawski, Refleksje rocznicowe. 1884-1930-1980/1984, w: Jan Kochanowski 1584-1984..., s. 371-390; U. Kowalczuk, 1884 - jubileuszowa „renowacja” Kochanowskiego, w: Upominki od narodu. Jubileusze, rocznice, obchody pisarzy, red. T. Budrewicz, P. Bukowski, R. Stachura-Lupa, Muzeum Marii Konopnickiej, Żarnowiec 2010, s. 103-119.

${ }^{7}$ Por. M. Fidelus, O wydawnictwach staropolskich tekstów literackich przed rokiem 1918 , „Ruch Literacki” 1971, z. 1, s. 45-50; J. Starnawski, Kronika edytorstwa naukowego w Polsce, w: tenże, Praca wydawcy naukowego, wyd. 2 poszerz., Zakład Narodowy im. Ossolińskich, Wrocław 1992, s. 147-160; M.M. Kacprzak, Edycje literatury staropolskiej w życiu Polaków XIX w. na przykładzie wydań „Zwierciadta” Mikołaja Reja, w: Na co dzień i od święta. Ksiązka w życiu Polaków w XIX-XXI wieku, red. nauk. A. Chamera-Nowak, D. Jarosz, Oficyna Wydawnicza ASPRA-JR, Warszawa 2015, s. 71-90. 
epokach kulturowo-literackich, także w epoce Młodej Polski. Szczególnie wyraziście wypowiedział ją Kazimierz Cysewski, autor znamiennie zatytułowanej książki Z zagadnień literaturoznawstwa polskiego doby pozytywizmu 1860-19148. Zważywszy, iż w drugiej połowie XIX w. i na progu wieku XX edytorstwu literackiemu coraz dobitniej wyznacza się cele naukowe, coraz precyzyjniej formułuje się jego naukową metodologię i metodę, a prace edytorskie podejmują przede wszystkim badacze historii literatury, istnieje pokusa, by stosować tę tezę także do określania relacji między młodopolską praktyką literacką a ówczesnym edytorstwem dzieł literackich (zwłaszcza dawnych, a więc będących raczej przedmiotem zainteresowania literaturoznawców niż krytyków literackich).

Cysewski w swych pracach $\mathrm{z}$ historii historiografii literatury, uogólniając, konstatuje, że

Młoda Polska stosunkowo słabo odbiła się na badaniach literackich, nie stworzyła własnej szkoły naukowej; obecność jej doświadczeń zaznaczyła się głównie właśnie w krytyce literackiej, w nauce zaś ich odzwierciedlenie ujawniło się najwyraźniej chyba w początkach dwudziestolecia międzywojennego [...]. Nadto nie był to okres stwarzający korzystny klimat dla rodzącej się racjonalistycznej nauki, pobudzający zainteresowania dla literatury, które mieściłyby się w „parametrach” naukowości ${ }^{9}$.

Przyjmując, ,że naukowe tendencje teoretyczno-metodologiczne zawsze trwają dłużej niż szkoła literacka, na której gruncie wyrosły"10, Cysewski przypomina prace Henryka Markiewicza, który „dostrzegając przekształcenia literaturoznawstwa z połowy XIX stulecia i początków wieku XX, zdaje się traktować je jako jedną formację badawczą""11 przede wszystkim jednak posługuje się w odniesieniu do literaturoznawstwa okresu modernizmu rozpoznaniami Konrada Górskiego:

W dobie Młodej Polski, gdy ludzie szaleli na punkcie „sztuki dla sztuki”, historycy literatury widzieli dzieło literackie oczyma pozytywistów [...]. [...] twórcy naszej historii literatury z lat 1860-1895 rozumowali o dziele literackim w sposób romantyczny, druga generacja - lata 1895-1914 - na modłę pozytywistyczną, a trzecia w latach 1918-1939- po młodopolsku' ${ }^{12}$.

\footnotetext{
${ }^{8}$ K. Cysewski, Z zagadnień literaturoznawstwa polskiego doby pozytywizmu 1860-1914, Wyższa Szkoła Pedagogiczna, Słupsk 1986.

${ }^{9}$ Tenże, Pozytywistyczna formacja literaturoznawcza, w: tenże, Między historia badań literackich a teoria literatury, Wydawnictwo Uniwersytetu Warmińsko-Mazurskiego, Olsztyn 2002, s. 11.

${ }^{10}$ Tamże, s. 12.

${ }^{11}$ Tamże, s. 13. Por. H. Markiewicz, Polska nauka o literaturze. Zarys rozwoju, PWN, Warszawa 1981.

${ }^{12}$ K. Cysewski, Pozytywistyczna formacja..., s. 12. Notabene Cysewski nie podziela tego przekonania w odniesieniu do romantycznego charakteru literaturoznawstwa po 1860 r. Por. K. Gór-
} 
Nie miejsce tu na miarodajną weryfikację tych uogólniających tez, wymagającą wnikliwej analizy ówczesnych rozpraw historycznoliterackich (także zamieszczanych w edycjach dzieł literackich). Zaznaczmy tylko, że wątpliwości budzi tu przede wszystkim wyraźne rozgraniczenie w epokach pozytywizmu i Młodej Polski literaturoznawstwa i krytyki literackiej, których wspólne drogi w praktyce pisania o literaturze Cysewski zresztą przypomina ${ }^{13}$. Bez względu jednak na skalę adekwatności tych wniosków, nie należy ich przyjmować jako przesłanki do separowania w badaniach zagadnień, dotyczących XIX-wiecznego edytorstwa dzieł staropolskich i światopoglądu modernistycznego. Bez względu na to, z jakimi założeniami i celami oraz przy użyciu jakich metod wydawano wówczas polskie teksty dawne, fakt, że stawały się coraz powszechniej dostępne, mógł oddziałać na poglądy i praktykę literacką zapoznających się z nimi pisarzy-modernistów.

Do badań nad tym możliwym wpływem zniechęcać mogą wnioski z dotychczasowych prac z zakresu recepcji literatury staropolskiej w epoce młodopolskiej; to opracowania najczęściej związane z twórczością Jana Kochanowskiego, a także Mikołaja Reja, budzące zainteresowanie przy okazji obchodów rocznic urodzin i śmierci pisarzy.

Zasadniczo wnioski te uzgadniają się z obrazem wynikającym z relacji Karola Wiktora Zawodzińskiego, krytyka literackiego, teoretyka i historyka sztuki, urodzonego w 1890 roku. Po wielu latach pisze on o stosunku, jaki do twórczości Jana Kochanowskiego miało jego pokolenie - ludzie wychowani już w intelektualnej i duchowej atmosferze modernizmu:

Wobec zasadniczego dążenia do określenia i zamanifestowania uniwersalnych wartości polskiej kultury, co legitymowałoby prawa narodu polskiego do tożsamości i upragnionej niepodległości, na plan pierwszy wysuwała się sztuka romantyczna: Szopen (w interpretacji Przybyszewskiego), Słowacki, ogłoszony przez I. Matuszewskiego prekursorem „nowej sztuki” europejskiej, a także Mickiewicz i odkrywany wówczas Norwid. Kochanowski, zamknięty w formule ojca polskiej poezji, czy ,praszczura polskiej pieśni”, obciążony romantycznym zarzutem braku oryginalności, nie spełniał neoromantycznych kryteriów i potrzeb epoki. Jego spuścizna nie mogła stanowić przedłużenia osiągnięć romantycznych w głąb historii, stawała się zatem - ze względów ideologicznych, a w równej mierze estetycznych także zupełnie nieprzydatna, w takim kształcie, w jakim poznało ją (za sprawą podręczników) młode pokolenie, wzrastające pod urokiem romantycznej trójcy wieszczów. [...] Rysy najcharakterystyczniejsze fizjognomii poetyckiej Kochanowskiego: jego trzeźwość,

ski, Przeglad stanowisk metodologicznych w polskiej historii literatury do 1939 roku, w: tenże, Rozważania teoretyczne. Literatura, muzyka, teatr, Redakcja Wydawnictw KUL, Lublin 1984, s. $12,15$.

${ }^{13}$ Por. K. Cysewski, Nauka o literaturze - krytyka literacka, w: tenże, Między historia badań literackich..., s. 67-89. 
stawiająca sobie ziemskimi granicami określone cele, jego ludzkość, jego prostota, były jak najdalsze od mistycznego ekstatyzmu, zatopienia się w nieskończonym, nadziemskości, nadludzkości czy nieludzkości - słowem - całego patosu wyczekiwanego od poezji w epoce mojej młodości”"14.

Wypowiedź Zawodzińskiego niewątpliwie ma prawo być uznana za wiarygodną; to przecież relacja świadka. Warto jednak zwrócić uwagę, że krytyk dokonuje uogólnień, kategoryzuje, operując dość stereotypowo ujętymi cechami omawianych epok i ich przeciwstawieniami. Młodą Polskę charakteryzuje tu skłonność do irracjonalizmu, transcendencji i mistycyzmu, oryginalności, skrajności ujęć, patosu i estetyki nieklasycznej, a także podkreślania łączności z kulturą europejską i tego, co uniwersalne w kulturze polskiej; jeśli chodzi o tradycję literacką, oznacza to kult romantyzmu, zinterpretowanego przez koryfeuszy nowej epoki wedle jej upodobań i potrzeb. Całkiem kontrastowe wobec tego rejestru cechy Kochanowskiego - najdoskonalszego poety staropolskiego, właściwie jej uosobienia - mają czynić jego poezję nieatrakcyjną ideowo i estetycznie, a przez to dla modernistów nieważną. To klarowne wyłożenie przez Zawodzińskiego, z czytelnym uzasadnieniem, stosunku Młodej Polski do kultury staropolskiej (a przynajmniej renesansowej) może przez swoją systematyczność narzucać się jako atrakcyjne historykom literatury, niejednokrotnie formułującym ogólne wnioski o zasadniczej nieprzystawalności ideałów staropolskich i młodopolskich mimo notowania nierzadkich ich spotkań.

Andrzej Z. Makowiecki, uwzględniwszy w artykule o młodopolskiej recepcji poezji czarnoleskiej nie tylko poezję Wacława Rolicz-Liedera oraz renesansyzm Staffa i „Museionu”, ale także twórczość Wyspiańskiego i „późnego Przybyszewskiego" ${ }^{15}$, formułuje sugestywnie wniosek (jak sam podkreśla, zgodny z sądem stereotypowym) o niechęci końca wieku XIX do tradycji staropolskiej, przezwyciężanej tylko na granicach epoki:

Centrum Młodej Polski i jej nurt modernistyczny, dominujący w dziesięcioleciu 1890-1900, [...] od tradycji czarnoleskiej w swoim programie literackim i jego praktycznych realizacjach raczej się odwraca. [...] Patronat ten [Kochanowskiego] i jego chronologiczne miejsce odnajdujemy więc jakby zgodnie z przedustawnym przekonaniem, że inspiracji czarnoleskich szukać trzeba na wschodzie i zachodzie Młodej Polski, nie w jej modernistycznym zenicie ${ }^{16}$.

Dobitniej stwierdza młodopolskie désintéressement dla myśli renesansowej Anna Niewolak-Krzywda, podsumowując swe szerokie i rzetelne omówienie dzie-

\footnotetext{
${ }^{14}$ K.W. Zawodziński, Czterdzieści lat z Kochanowskim, czyli metamorfozy pojęcia poezji, „Twórczość” 1946, z. 5, s. 59, 60.

${ }^{15}$ Por. A.Z. Makowiecki, Młoda Polska..., s. 336.

16 Tamże, s. 340.
} 
więtnastowiecznych dziejów „,rzeczy czarnoleskiej”, w którym skądinąd przypomniała wiele faktów wskazujących na młodopolskie uobecnienia staropolszczyzny:

W literaturze dziewiętnastowiecznej [...] cytaty i odwołania do dzieł i myśli poety [Kochanowskiego] służyły bądź pomnożeniu „poczciwej sławy”, bądź aktualnym celom agitacyjno-dydaktycznym. Nie spotyka się natomiast prób filozoficznej czy artystycznej reinterpretacji dzieła czarnoleskiego. Spostrzeżenie powyższe odnieść można także do literatury pierwszego dwudziestolecia naszego wieku ${ }^{17}$.

Pamięć o literaturze staropolskiej i nawiązania do niej nie muszą oczywiście oznaczać silnego wpływu na dominujący w Młodej Polsce światopogląd i na główny nurt twórczości. Mogą więc zostać obronione te ogólne wnioski badaczy jako odnoszące się do tego, co dominujące i główne. Warto jednak podkreślić fakt, że niejako sprzeczne z tymi wnioskami obserwacje szczegółowe wiążą się z postaciami, których z pewnością nie można uznać za marginalne w polskim modernizmie:

[...] w fazie środkowej tej epoki, tj. w ostatnich latach XIX i pierwszych XX w., inspiracje płynące z poezji Kochanowskiego docierają wyraźniej chyba jedynie do Stanisława Wyspiańskiego ${ }^{18}$.

Nie spotyka się również [w literaturze dziewiętnastowiecznej] twórczego sięgnięcia po spuściznę Jana Kochanowskiego - poza jednym, ale charakterystycznym wyjątkiem: w niedokończonym dramacie Stanisława Wyspiańskiego [...]. Obecność spuścizny czarnoleskiej w świadomości twórczej pisarzy młodopolskich tej miary co Przybyszewski i Wyspiański nie miała wpływu na stosunek epoki do twórczości Kochanowskiego $[\ldots]^{19}$.

Zbyt ważkie są owe miejsca spotkania staropolskiego z młodopolskim, by warto było poddawać się sugestii, iż z dotychczasowych badań wynika małe znaczenie kontaktu Młodej Polski z tekstami staropolskimi dla badania światopoglądu (światopoglądów) modernizmu.

Zwłaszcza że w życiu literackim lat 1890-1914 zaobserwować można wiele przejawów zainteresowania literaturą i kulturą dawną. Szczególna jest tu pozycja renesansu, zawdzięczana przede wszystkim recepcji dzieła Die Kultur der Renaissance In Italien. Ein Versuch z 1860 roku, autorstwa Jacoba Burckhardta, traktowanego z estymą jako mistrz Friedricha Nietzschego i dzielącego z nim fascynację renesansowym indywidualizmem (oraz zwykle interpretowanego przez pryzmat tez Nietzschego). Urszula Kowalczuk w książce o stosunku polskich

${ }^{17}$ A. Niewolak-Krzywda, W kręgu rzeczy czarnoleskiej, Krajowa Agencja Wydawnicza, Rzeszów 1987, s. 94-100.

18 A.Z. Makowiecki, Młoda Polska..., s. 335.

${ }^{19}$ A. Niewolak-Krzywda, dz. cyt., s. 96, 100. 
pisarzy drugiej połowy XIX w. do renesansu szczegółowo omawia i wnikliwie interpretuje liczne fakty, poświadczające to modernistyczne zainteresowanie renesansem, w różnym stopniu związane z tezami Burckhardta i Nietzschego ${ }^{20}$. Tu przypomnijmy tylko za badaczką, że w latach 1895-1897 wydano w Krakowie polski przekład Kultury odrodzenia we Włoszech ${ }^{21}$, komentowany w recenzjach przez Antoniego Langego i Piotra Chmielowskiego ${ }^{22}$, wcześniej opublikowano także tłumaczenia Odrodzenia $i$ humanizmu we Włoszech $i$ Niemczech, napisanego w 1882 roku przez współpracownika i redaktora Burckhardta - Ludwiga Geigera $^{23}$ (wydanie opatrzył komentarzem Piotr Chmielowski), oraz Filozofii sztuki Hipolita Taine'a z 1865 roku (jego Podróż po Włoszech z 1866 roku wydano w 1908 roku ${ }^{24}$; interpretacje zawartych w tych książkach sądów znaleźć można w publikowanych wcześniej i później wypowiedziach Georga Brandesa, Marii Przewóskiej, Zofii Daszyńskiej, Hansa Vaihingera, Wacława Berenta czy wreszcie Stanisława Przybyszewskiego, choć ten nad renesans przedkładał gotyk $^{25}$. Otwartość polskiego modernizmu na dialog z kulturą dawną, w której rozpoznawano źródło wzorców i antywzorców dla wizji człowieka i artysty, nie ulega wątpliwości.

Z punktu widzenia badań nad rolą edytorstwa dzieł staropolskich w kulturze młodopolskiej interesujące są jednak przede wszystkim takie zjawiska życia literackiego modernizmu, które odsłaniają ewidentne zainteresowanie konkretnym tekstem staropolskiego dzieła lub tego tekstu znajomość, a także zaświadczają odczytywanie jego wymowy ideowej przez pryzmat aktualiów modernizmu

${ }^{20}$ Por. U. Kowalczuk, Powinność i przygoda. Pisarze polscy drugiej połowy XIX wieku wobec kultury renesansu, Wydział Polonistyki UW, Warszawa 2011.

${ }^{21}$ J. Burckhardt, Kultura odrodzenia we Wtoszech, tłum. wg III wydania, popr. przez L. Geigera, przez L. M.[ycielską], t. I, Spółka Wydawnicza Polska, Kraków 1895, t. II, Spółka Wydawnicza Polska, Kraków 1897.

22 A. Lange, J. Burckhardt „Kultura Odrodzenia we Włoszech”, „Ateneum” 1896, t. I, z. 3 , s. 587-592; P. Chmielowski, Z czasów Odrodzenia (Jacob Burckhardt „Kultura Odrodzenia we Włoszech”), „Kurier Codzienny” 1897, nr 307.

${ }^{23}$ L. Geiger, Odrodzenie i humanizm we Włoszech i Niemczech, przeł. S. Mieczyński, druk. S. Lewentala, Warszawa 1896.

${ }^{24}$ H. Taine, Filozofia sztuki, przeł., przypisami i skorowidzem opatrzył A. Sygietyński, druk. S. Lewentala, Warszawa 1896; tenże, Podróż po Włoszech, przeł. A. Sygietyński, wyd. nowe, opatrzone objaśnieniami, Księgarnia Powszechna, Warszawa 1908.

${ }^{25}$ Por. G. Brandes, Umysty wspótczesne. Portrety literackie XIX wieku, przeł. M. Posner-Garfein, t. 2, Redakcja „Głosu”, Warszawa 1894; M. Przewóska, Fryderyk Nietzsche jako moralista i krytyk. Studium filozoficzne, H. Cohn, Warszawa 1894; Z. Daszyńska, Nietzsche-Zarathustra. Studium literackie, Drukarnia Narodowa F.K. Pobudkiewicza, Kraków 1896; J. Vaihinger, Filozofia Nietzschego, przeł. K. Twardowski, H. Altenberg - E. Wende, Lwów-Warszawa 1904; W. Berent, Źródła i ujścia nietzscheanizmu, „Chimera” 1905, t. IX, z. 25, s. 118-139. Por. U. Kowalczuk, Powinność i przygoda..., s. 33-126; T. Weiss, Fryderyk Nietzsche w piśmiennictwie polskim lat 1890-1914, PWN, Warszawa 1961; M. Kopij, Friedrich Nietzsche w literaturze i publicystyce polskiej lat 1883-1918. Struktura recepcji, Wydawnictwo Poznańskie, Poznań 2005. 
- w kategoriach punktu odniesienia, tematu do dyskusji, wzorca czy modelu odrzucanego, słowem - zjawiska, którego akceptacja lub negacja może kształtować modernistyczny światopogląd. Przykładów takich zjawisk nie brakuje.

W 1899 roku Bronisław Chlebowski napisał do Prawdy. Ksiązki zbiorowej dla uczczenia dwudziestopięcioletniej działalności Aleksandra Świętochowskiego artykuł Indywidualizm jako czynnik rozwoju artyzmu polskiego w wieku XVI, a jako kwintesencję tak pojętego indywidualizmu przedstawił dzieło Jana Kochanowskiego, wspominając też o innych silnych duchem i uczuciem jednostkach: Klemensie Janicjuszu czy Mikołaju Reju. Niezależnie od przyjęcia perspektywy historycznoliterackiej oraz kontekstu związanego z ,papieżem pozytywizmu”, mamy tu do czynienia, jak trafnie zauważył Makowiecki, z ujęciem związanym ze świadomością modernistyczną ${ }^{26}$. Centralne kategorie służące do opisu kultury literackiej renesansu - ,indywidualizm” (też ,indywidualność”, ,jednostka”, „samoistne życie duchowe”, ,energia niezłomnej woli”, ,energia i poczucie indywidualne”, „,poczucie indywidualnej wyższości, opartej na potędze umysłowej”, ,dusza wyżej rozwiniętych jednostek”) oraz ,artyzm” (też ,sztuka”) ${ }^{27}$ - w sposób oczywisty z niej wynikają. To ujęcie z perspektywy końca wieku XIX ujawnia się już w nagłosie tekstu:

Rozkwit uzdolnień artystycznych, stanowiący najwybitniejszy pojaw we współczesnym życiu duchowym naszego społeczeństwa, nasuwać musi obserwatorom tego zjawiska zapytanie o początki sztuki polskiej, o genezę naszego artyzmu² ${ }^{28}$.

Twórczość Kochanowskiego, przywoływana nie na podstawie wiedzy ogólnej, ale bardzo konkretnie cytowana i interpretowana na podstawie fragmentów Szachów, Satyra, Zgody, Proporca, Muzy, Odprawy postów greckich, Psalterza Dawidowego, Fraszek, Pieśni i Trenów, zostaje tu zestawiona równorzędnie z Dziadami, dziełem niepodważalnej indywidualności artystycznej, ,wielkiego wieszcza naszego wieku", co ma w epoce neoromantyzmu znaczenie szczególne, a kulminuje w poincie artykułu:

Ta wspólność momentów rozwoju duchowego nadaje postaci Kochanowskiego piętno nowożytne i ogólno-ludzkie zarazem, artyzm zaś jego zawdzięcza swe znamiona charakterystyczne przeważnie rozwojowi indywidualizmu, złączonemu z procesem moralnym, dostarczającym osnowy dla większości utworów poety ${ }^{29}$.

${ }^{26}$ Por. A.Z. Makowiecki, Młoda Polska..., s. 337.

${ }^{27}$ B. Chlebowski, Indywidualizm jako czynnik rozwoju artyzmu polskiego w wieku XVI, w: Prawda. Książka zbiorowa dla uczczenia dwudziestopięcioletniej działalności Aleksandra Świętochowskiego. 1870-1895, Księgarnia H. Altenberga - K. Grendyszyński, Lwów-Petersburg 1899, s. 80-93.

28 Tamże, s. 80.

29 Tamże, s. 93. 
Chlebowski niewątpliwie jest dzieckiem swoich czasów, ale nie reprezentuje światopoglądu modernistycznego w sposób najbardziej oczywisty. Ostrożność, z jaką włączamy jego wypowiedzi do naszych rozważań, może zniknąć w odniesieniu do Ignacego Matuszewskiego; znika w odniesieniu do pisarza młodszego i do wypowiedzi późniejszej, ale przede wszystkim znika wraz z przejściem od historii literatury, która graniczy z krytyką literacką, do krytyki literackiej, która snuje refleksję nad historią literatury. W 1903 roku w szkicu Wzniostość u Słowackiego (Przyczynek do psychologii geniuszu poety), pełniącym funkcję przedmowy do wydania Dzieł Juliusza Słowackiego ${ }^{30}$, Matuszewski zestawia Słowackiego z Mickiewiczem oraz Kochanowskim, aby precyzyjniej przedstawić kategorię estetyczną wzniosłości w jego twórczości i ukazać jego wyjątkowość na tle poezji polskiej, w której „na ogół dążenie do piękna przeważało nad dążeniem do wzniosłości" ${ }^{31}$. Matuszewski porównuje obrazy poetyckie relacji człowiek - Bóg w Pieśni „Czego chcesz od nas, Panie...” i we fragmencie Beniowskiego („Kto Cię nie widział nigdy, wielki Boże...”), widząc w wierszu staropolskim zarówno kategorię piękna, jak i wzniosłości, i diagnozując w nim przewagę kategorii drugiej ${ }^{32}$; dominację wzniosłości nad pięknem stwierdza natomiast w Trenach, cytując fragment zakończenia Trenu X. Niewątpliwie młodopolskiemu krytykowi bliższy jest poeta romantyczny niż renesansowy. Jednak poetę staropolskiego ceni bardzo wysoko, zna go z lektury, cytuje i analizuje tekst jego utworu. Interpretacja jego wizji świata pomaga moderniście doprecyzować sądy na temat poety romantycznego oraz jasno sformułować własne koncepcje estetyczne i ideowe.

Na przełomie wieków świadectwo zainteresowania Kochanowskim, lektury jego utworów i ich docenienia jako wzorca artystycznego dała Gabriela Zapolska, w związku z pracami nad, słabą zresztą artystycznie, sztuką, stanowiącą adaptację powieści Klementyny z Tańskich Hoffmanowej Jan Kochanowski w Czarnolesie. Obraz z końca XVI wieku z 1842 roku; napisany w 1896 roku komediodramat Jan Kochanowski wystawiano na różnych scenach w latach 1899-1902 pod tytułem Urszulka z Czarnolasu. W okresie sukcesu sztuki w warszawskim Wodewilu w 1899 roku Zapolska pisała ${ }^{33}$ : „Za to Kochanowskiego teraz dopiero poznałam i jestem w nim rozkochana. Takie słowa: „«Śnie, który uczysz umierać człowieka!». Co przy nich Szukiewicze i inne połamańce!”34.

${ }^{30}$ I. Matuszewski, Wzniostość u Słowackiego (Przyczynek do psychologii geniuszu poety), w: J. Słowacki, Dzieła (wydanie ilustrowane), red. F. Hoesick i L. Méyet, z przedm. I. Matuszewskiego, t. I, Redakcja „Wędrowca”, Warszawa 1903, s. V-XXIV.

${ }^{31}$ Tamże, s. XIII.

32 Por. A.Z. Makowiecki, Młoda Polska...., s. 336-337.

${ }^{33}$ Por. tamże, s. 333; A. Niewolak-Krzywda, dz. cyt., s. 92-93.

${ }^{34}$ G. Zapolska, Listy, oprac. S. Linowska, t. I, Państwowy Instytut Wydawniczy, Warszawa 1970, s. 654. 
Obserwujemy tu świeżą fascynację po raz pierwszy lub na nowo przeczytanymi wierszami Kochanowskiego, świadectwo lektury konkretnego tekstu i refleksji nad nim, która musiała mieć miejsce podczas pracy nad dramatem. Nie zaskakuje zainteresowanie młodopolskiej pisarki sugestywnym metaforycznym obrazem snu i śmierci, wyczulenie na elementy dawnej kultury adekwatne do współczesnej wrażliwości. Szczególnie ciekawe zdaje się jednak owo żartobliwo-złośliwe w tonie, ale tym bardziej pobrzmiewające szczerością, stwierdzenie wyższości artystycznej renesansowego poety nad przeciętną twórczością młodopolską. Gdy w metonimicznym sformułowaniu, które przywołuje postać krakowskiego poety, prozaika, dramaturga i krytyka Macieja Szukiewicza, krytykuje Zapolska słabość artystyczną współczesnej literatury, Kochanowski objawia się jako poeta lepszy - zapewne w sferze stylistycznej, dzięki klarowności klasycznej formy, ale i w mocy wyrazu ideowego.

Podobny sposób myślenia o Kochanowskim łączy się z wystawieniem Odprawy postów greckich w 1907 roku. Teatry Warszawskie uznały wówczas ten dramat za wart przypomnienia jako otwierający dzieje poezji i teatru w Polsce. Władysław Bukowiński, niebawem już założyciel i wydawca miesięcznika literacko-artystycznego i naukowego „Sfinks”, pisał w „Prawdzie”, recenzując wystawienie swoistej historii polskiego teatru ${ }^{35}$ :

Stara tragedia Kochanowskiego budziła podziw przyjemny; ten i ów poczuł nieco zadowolenia i dumy, że to u nas, panie, przed trzystu kilkudziesięciu laty takie rzeczy pisano już i wystawiano. Jędrny i pełen głębszej myśli patriotycznej wiersz Kochanowskiego rozbrzmiewał pięknie [...] I komedyi dworskiej Baryki [...] słuchano nie bez zajęcia [...] jeśli o zaznaczenie rozwoju sztuki polskiej chodziło, można było pominąć i Barykę z tańcami, i żywy obraz obiadu czwartkowego, przechodząc bezpośrednio od Kochanowskiego do pominiętych zupełnie Fredry i Słowackiego i dając na zakończenie choć dwie sceny z Wesela ${ }^{36}$.

Dla krytyka młodopolskiego kolejne etapy rozwoju polskiego teatru znaczą nazwiska Kochanowskiego jako protoplasty, Słowackiego - „kanonizowanego” w tym czasie mistrza neoromantyków, Fredry (może jako patrona początków dramatu typu naturalistycznego) i wreszcie Wyspiańskiego z Weselem, jako zapewne najwyższym osiągnięciem dramaturgii modernistycznej w Polsce. Kochanowski może spotkać się w jednym spektaklu ze Słowackim i Wyspiańskim, i to nie jako

\footnotetext{
${ }^{35}$ Por. J. Lewański, „Odprawa postów greckich” w teatrach XIX i XX wieku, w: Jan Kochanowski i epoka renesansu. W 450 rocznice urodzin poety 1530-1980, red. T. Michałowska, PWN, Warszawa 1984, s. 382; W. Namerła, Inscenizacje „Odprawy postów greckich” 1870-1978, „Pamiętnik Teatralny" 1978, z. 3, s. 365-382.

${ }^{36}$ W. Bukowiński, Przegląd teatralny, „Prawda” 1907, nr 44, s. 521-522.
} 
pobłażliwie potraktowany, jedyny znaleziony w pomroce dziejów punkt wyjścia dla dalszego postępu, ale jako autor zaskakujący jakością artystyczną i ideową nowatorskiego wówczas dzieła - „u nas [...] przed trzystu kilkudziesięciu laty takie rzeczy pisano już i wystawiano". Być może w tej wypowiedzi i w koncepcji spektaklu, do którego się ona odnosi - a który zaznajamiał szersze grono odbiorców w tekstami dramatów staropolskich - napotykamy także ślad dostrzeżenia przez współczesnych pewnego pokrewieństwa artystyczno-ideowego ,antycznych" dramatów Wyspiańskiego z Odprawa posłów greckich, dziełem rzeczywiście w swoim czasie nowatorskim.

I wreszcie casus nie do pominięcia: Stanisław Przybyszewski. W 1913 roku w liście do Henryka Biegeleisena nie tak jeszcze ,późny” Przybyszewski daje swoistą próbę autobiografii, w której ukazuje - może to poza, może prowokacja - swoje młodzieńcze lektury i pierwsze wzory literackie ${ }^{37}$. Za skłonność późniejszego modernisty do artystycznego wykorzystywania form i treści religijnych odpowiadać ma spotkanie - w kościele parafialnym i domowej biblioteczce - ze średniowiecznymi hymnami kościelnymi i staropolską literaturą religijną:

Skąd ja wziąłem moją - przynajmniej w moich poematach - tę liturgiczną, że tak powiem, formę?

Stamtąd - tylko stamtąd! Z litanii i antyfon, z psałterza Dawidowego Kochanowskiego, w którym się z rozkoszą rozczytywałem, z przepięknego modlitewnika, ułożonego, jeżeli się nie mylę, przez księdza-poetę Antoniewicza, a żaden, najpotężniejszy nawet twór artystyczny nie zdołałby silniejszego wrażenia na mnie wywrzeć, jak pieśni kościelne „Dies irae”, „Święty Boże, Święty Mocny”, „Witaj Królowo” - i zdumiewające: te same rzeczy, które duszę Kasprowicza zapłodniły.

W ojca bibliotece, jak na nauczyciela wiejskiego bardzo zasobnej, [...] „Kazania” Skargi i jego „Żywoty świętych”, które prawie na pamięć umiałem³.

Przekonanie Przybyszewskiego o wartości poezji czarnoleskiej i potrzebie jej ukazywania współczesnym, także włączenia jej w szerszy obieg czytelniczy w Europie, zaowocowało projektem (niezrealizowanym, choć najwyraźniej nie nierealnym, skoro wydawnictwo wypłaciło zaliczkę) wydania niemieckiego przekładu wyboru dzieł Kochanowskiego. W 1916 roku pisał Przybyszewski do Aleksandra Guttrego ${ }^{39}$ o tym wyzwaniu pracy translatorskiej nad tekstem staropolskim, którą najwyraźniej zamierzał realizować w stylizacji archaizującej:

\footnotetext{
${ }^{37}$ Por. A.Z. Makowiecki, Młoda Polska..., s. 335.

${ }^{38}$ S. Przybyszewski, Moja autobiografia, „Wiadomości Literackie” 1928, nr 18, s. 2.

${ }^{39}$ Por. A.Z. Makowiecki, Młoda Polska..., s. 336.
} 
Teraz co do wyboru pism Kochanowskiego w thumaczeniu niemieckim $[\ldots]$ podejmuję się tej nad wszelki wyraz trudnej pracy [...]. Na szczęście znam gruntownie język niemiecki z epoki Lutra, więc dlatego jedynie do thumaczenia Kochanowskiego się zabiorę ${ }^{40}$.

W 1917 roku Przybyszewski poświęca Kochanowskiemu dużo uwagi w szkicach Szlakiem duszy polskiej. Opisując ewolucję kultury polskiej, uznaje go za twórcę, który pierwszy objawił jej samoświadomość, niezależność i siłę. Widzi w jego dziele połączenie kosmopolityzmu i rodzimości (na przykład w próbach w zakresie tragedii antycznej - Odprawie postów greckich), analogiczną do przedsiębranej przez modernistów syntezę kultury zachodniej i narodowej. Postać i twórczość Kochanowskiego interpretuje Przybyszewski wprost w kategoriach modernizmu ${ }^{41}$ :

[...] bezwarunkowo największym modernistą w Polsce był Kochanowski: wyparł wszechwładny język łaciński z poezji polskiej i stworzył z mocno poniewieranej czesko-polskiej „lingua vulgaris” wytworną, szlachetną, niezmiernie subtelną harfę ${ }^{42}$.

Doskonała językowo, subtelna twórczość renesansowa poety, pozbawionego kompleksów i odważnego, wrażliwego na wyzwania sztuki współczesnej, jest w oczach Przybyszewskiego pokrewna myśli i dziełu modernistów.

Wreszcie już w 1926 roku w odczycie o Janie Kasprowiczu, snując teorię rozwoju kultury narodowej jako dziejów wzrostu duszy polskiej, przejawiającego się szczególnie w trójcy poetów: Kochanowski - Mickiewicz - Kasprowicz, nazwie Przybyszewski „największego modernistę w Polsce” także „twórcą potęgi duchowej duszy polskiej”³. Zważywszy wcześniejsze świadectwa lektur, nie ma wątpliwości, że ta wizja wspiera się na lekturze konkretnych tekstów staropolskich.

Trudno nie zauważyć, analizując te przykłady modernistycznej otwartości na dziedzictwo tekstów staropolskich i ich wiązania ze światopoglądem współczesnym, że mamy tu do czynienia z młodopolską interpretacją staropolszczyzny, uwrażliwieniem na niektóre utwory, tematy i motywy, rezonowaniem tego, co daje się w określonych warunkach ideowo-estetycznych zrozumieć, przyjąć czy zawłaszczyć. Trzeba jednak podkreślić: nawet jeżeli młodopolski dialog ze staropolszczyzną opiera się na sądach uprzednich i założonych celach, to jednak w wielu uchwytnych przypadkach spotkanie młodopolskiego ze staropolskim

${ }^{40}$ S. Przybyszewski, list do Aleksandra Guttego z 6 IV 1916 r., w: tenże, Listy, t. II, „Parnas Polski", Warszawa 1938, s. 645.

${ }^{41}$ Por. A.Z. Makowiecki, Młoda Polska..., s. 336.

42 S. Przybyszewski, Szlakiem duszy polskiej, Ostoja, Poznań 1917, s. 110.

${ }^{43}$ Por. A. Niewolak-Krzywda, dz. cyt., s. 94-96. 
nie jest pozorne, ale opiera się na faktycznej lekturze konkretnego tekstu literackiego. Uobecniona w dziewiętnastowiecznych edycjach (zasadniczo nie czytano przecież wydań staropolskich) literatura staropolska mogła utwierdzać młodopolski światopogląd i mogła go modyfikować.

Przy tej świadomości, w badaniach wpływu dziewiętnastowiecznego edytorstwa tekstów dawnych na światopogląd modernizmu musimy koniecznie zachować ostrożność. Samo dostrzeżenie chronologicznego następstwa wydań i podobieństwa tematyki czy zainteresowań pisarza młodo- i staropolskiego nie wystarczy, by stwierdzić oddziaływanie przyczynowe. By wyraźnie zobrazować - anegdotycznie - to zjawisko i związane z nim możliwe nadużycia, posłużmy się przykładem współczesnym. Z faktu, że w 2006 roku w wydaniu krytycznym udostępniono po raz pierwszy od XVI w. dzieło Mikołaja Reja Apocalypsis ${ }^{44}$, stanowiące ewangelicki komentarz autora $\dot{Z}$ ywota człowieka poczciwego do biblijnej Księgi Objawienia św. Jana, nie wynika oddziaływanie tej edycji na poezje Jarosława Marka Rymkiewicza z wydanego w tym samym roku tomu Do widzenia gawrony ${ }^{45}$, choć poeta jest obeznanym z historią literatury filologiem, choć jego twórczość wpisuje się w nurt klasycyzmu pojmowanego jako odwołanie do tradycji literackiej (także poezji staropolskiej odbiegającej od wzorców antycznych), choć łączy on w wizjach poetyckich obraz swojskiego ogrodu z pytaniami metafizycznymi i eschatologicznymi ${ }^{46}$. Z publikacji tej edycji w 2006 roku nie wynika także oddziaływanie Apocalypsis Reja na Moje pierwsze samobójstwo Jerzego Pilcha ${ }^{47}$, choć pisarz ten chętnie eksponuje swoje związki z kulturą protestancką, choć jego książka, pełna humoru i ironii, bliska jest anegdocie i potoczystej gawędzie, choć ukazuje człowieka wobec cielesnej realności, ale i metafizyki w otaczającym świecie ${ }^{48}$. W obydwu przypadkach można, nawet bez lektury dzieł, wskazać po kilka haseł wspólnych pisarzom współczesnym i ich konkretnym dziełom oraz staropolskiemu pisarzowi o temperamencie gawędziarza, talencie malarza natury i życia codziennego, wyznającemu chrześcijańskie zasady oraz wrażliwemu na sferę metafizyczną i eschatologię. Aby jednak mówić o wpływie edycji tekstu staropolskiego na dzieło literackie i jego wymowę, potrzeba więcej danych: szczególne znaczenie ma oczywiście zaświadczająca lekturę tekstu staropolskiego wypowiedź dziewiętnastowiecznego autora; przekonywać mogą informacje biograficzne, wskazujące na przykład na znajomość pisarza z edytorem

${ }^{44}$ M. Rej, Apocalypsis, red. W. Kriegseisen, oprac. M.M. Kacprzak, S. Kawczyński, J.T. Maciuszko, I. Winiarska, Wydawnictwo Naukowe „Semper”, Warszawa 2005 [druk 2006].

45 J.M. Rymkiewicz, Do widzenia gawrony, Wydawnictwo Sic!, Warszawa 2006.

${ }^{46}$ Por. http://www.wydawnictwo-sic.com.pl/ksiazka/146/Do-widzenia-gawrony/kategoria_7/ [dostęp 28.07.2015].

${ }^{47}$ J. Pilch, Moje pierwsze samobójstwo i dziewięć innych opowieści, Świat Książki, Warszawa 2006.

${ }^{48}$ Por.http://www.swiatksiazki.pl/ebooki/moje-pierwsze-samobojstwo-e-book-jerzy-pilch-3400206/ [dostęp 28.07.2015]. 
czy znajomość edycji w środowisku pisarza (choćby przez program jego studiów); rozstrzygać mogą, rzecz jasna, ewidentne zbieżności tekstowe; ważne przesłanki stanowić może i obecność motywów, których najbardziej oczywistym źródłem jest niedawno wydany staropolski utwór. Aby mówić o możliwym wpływie dziewiętnastowiecznego edytorstwa na dzieło i myśl modernisty, zawsze trzeba móc wskazać jako źródło lekturę tekstu dawnego, nie ogólną wiedzę czy ogólne wyobrażenie, ale właśnie znajomość tekstu, która nie byłaby możliwa lub byłaby utrudniona bez jego dziewiętnastowiecznego wydania.

Takie ewidentne inspiracje przeczytanym „na świeżo” czy czytanym „na bieżąco" tekstem staropolskim można zauważyć w twórczości Stanisława Wyspiańskiego. Mówiono niejednokrotnie, i słusznie, o podobieństwach ważnych aspektów jego twórczości do modelu twórczości Kochanowskiego - w zakresie łączenia elementów kultury biblijnej i antycznej, mitów klasycznych i spraw polskich, wyobrażeń o wsi ${ }^{49}$. Warto zadać pytanie o konkretną drogę docierania wizji staropolskich do twórczości Wyspiańskiego, między innymi o lektury artysty. Interesujące może być na przykład, jaką edycję Trenów Kochanowskiego miał w ręku Stanisław Wyspiański, pisząc u kresu życia, niedokończony niestety, dramat Zygmunt August. Z powstałych pięciu scen (cztery opublikowano w 1907 roku w „Przeglądzie Powszechnym”, „Nowej Reformie” i „Krytyce”, piątą - pośmiertnie w 1908 roku w „Przeglądzie Powszechnym”, w 1917 i 1918 roku przedrukowano wszystkie w „Głosie Narodu” i „Maskach”) dwie (scena VI, czyli pożegnanie Zygmunta Augusta z umierającą Barbarą Radziwiłłówną, i scena VII z monologiem króla po śmierci królowej) wykazują bezpośrednią zależność tekstową od Trenów (przede wszystkim Trenu V, VII, VIII, IX, XIX). Tekst Kochanowskiego podlega oczywiście transpozycji: jego bohaterów - ojca-poetę i niespełna trzyletnią córkę - zastępują królewscy kochankowie. Ładunek ideowy dzieł, mówiących o niemożności zrozumienia i trudności zaakceptowania śmierci istoty młodej, pięknej, niewinnej i kochanej, o bezradności wobec pustki narzucającej się w szczegółach codzienności, o dramatycznym pragnieniu spotkania za wszelką cenę $e^{50}$, jest zbieżny, ale nie może być tożsamy w kontekście kryzysu antropologii renesansowego humanizmu oraz pytań o śmierć, które stawiał umierający artysta fin de siècle'u. Kształt estetyczny i ideowy ostatniej wypowiedzi literackiej Wyspiańskiego jest oryginalny, ale wiele zawdzięcza Trenom Kochanowskiego i odczytaniu ich sensów światopoglądowych. Wnikliwa analiza tekstu Zygmunta Augusta być może pozwoli odpowiedzieć na pytanie, jaki tekst Trenów leżał na biurku modernisty. Czy to jeszcze „Wydanie pomnikowe” Dziet wszystkich z 1884 roku, staranne i komentowane wydanie krytyczne, w którym Treny

${ }^{49}$ Por. K. Czachowski, Obraz współczesnej literatury polskiej, t. II, Państwowe Wydawnictwo Książek Szkolnych, Lwów 1934, s. 153; A.Z. Makowiecki, Młoda Polska..., s. 335; A. Niewolak-Krzywda, dz. cyt., s. 96-100.

${ }^{50}$ Por. tamże, s. 9. 
ukazują się w kontekście całej twórczości czarnoleskiej? Czy to któraś z kilku samoistnych edycji Trenów z lat osiemdziesiątych - wydanie popularne „Biblioteki Mrówki" drukowane we Lwowie, Gródku lub Krakowie, krakowskie facsimile czy lwowskie wydanie szkolne? Złoczowska wspólna edycja Trenów i Odprawy posłów greckich z 1902 roku czy może Treny w warszawsko-krakowskim miniaturowym Wyborze pism z Matejkowskim portretem Kochanowskiego? ${ }^{51}$ Odpowiedź może dopełnić lub zmienić wyobrażenie o warsztacie Wyspiańskiego czy jego profilu intelektualnym, wpłynąć na obraz artysty i wiedzę o sposobie kształtowania się jego światopoglądu i wizji artystycznych. Jeśli chodzi o interpretację jego dzieła, może dodać do niej tylko niuanse, ale być może ważne, na przykład gdy lepiej zrozumiemy dany motyw czy obraz, spostrzegłszy jego powiązanie z objaśnieniami do danej edycji czy z innym dziełem Kochanowskiego współwydanym w danej edycji z Trenami.

Czasem odpowiedź na takie pytania może skierować interpretację na nowe tory. Biorąc to pod uwagę, warto na przykład zastanowić się, czy zainteresowanie Wyspiańskiego krakowską średniowieczną historią konfliktu króla Bolesława Śmiałego ze św. Stanisławem biskupem, owocujące dramatami Bolesław Śmiały z 1903 roku i Skatka z 1907 roku, mogło się wiązać także z lekturą kroniki Galla Anonima, najstarszego źródła historycznego do tego tematu. Wydana kilkakrotnie od początku XIX w. do lat siedemdziesiątych, została przypomniana w 1899 roku we lwowskiej edycji Stanisława Kętrzyńskiego i Ludwika Finkela ${ }^{52}$, ułatwiającej lekturę jako przeznaczona na użytek szkolny, a inspirującej także nowe przystępne opracowania, między innymi książkę Kętrzyńskiego Gall-Anonim i jego kronika z 1898 roku $^{53}$ oraz szkice historyczne o XI w. Tadeusza Wojciechowskiego z 1904 roku z artykułem Factum biskupa Stanisława ${ }^{54}$.

Czasem pytając o wpływ edytorstwa tekstów dawnych na światopogląd końca wieku, warto wyeksponować fakt znany, ale nie wykorzystywany w interpretacjach. Dotyczy to na przykład dramatu Jana Kasprowicza Marcholt gruby a sprośny. Jego narodzin, życia i śmierci misterium tragikomiczne, ważnego, choć niedocenionego dzieła, wydanego wprawdzie dopiero w 1920 roku, ale dojrzewającego w myśli i warsztacie poety zapewne od około $1900 \mathrm{roku}^{55}$. Ty-

\footnotetext{
${ }^{51}$ Por. K. Estreicher, Bibliografia polska, cz. 1: Bibliografia XIX stulecia, wyd. 2, t. XVII, s. 75-86 (hasło: Kochanowski Jan).

52 Galli Anonymi chronicon, wyd. S. Kętrzyński, L. Finkel, Lwów 1899, „Fontes rerum Polonicarum in usum scholarum", t. 1.

${ }^{53}$ S. Kętrzyński, Gall-Anonim i jego kronika, nakł. Akademii Umiejętności, Kraków 1898.

${ }^{54}$ T. Wojciechowski, Szkice historyczne jedynastego wieku, nakł. Akademii Umiejętności, Kraków 1904.

55 J. Kasprowicz, Marchołt gruby a sprośny. Jego narodzin, życia i śmierci misterium tragikomiczne, Gubrynowicz, Lwów 1920. Por. A. Podstawka, Świat, który się nie kończy. Człowiek i transcendencja $w$ teatrze Jana Kasprowicza, Wydawnictwo KUL, Lublin 2014, s. 333-420; M. Sosnowski, Światopogląd Jana Kasprowicza. Elementy i fazy rozwoju, w: Pro memoria. Jan
} 
tuł i postać głównego bohatera w oczywisty sposób przywołują średniowieczną prześmiewczą opowieść, utrwaloną w literaturze polskiej w Rozmowach, które miat król Salomon mądry z Marchołtem grubym a sprośnym Jana z Koszyczek z 1521 roku, drukowaną w XIX w. kilkukrotnie we fragmentach i wreszcie udostępnioną w 1913 roku w edycji krytycznej - opartej na wszystkich znanych wersjach i opatrzonej studium bibliograficznym - przez Ludwika Bernackiego, historyka polskiej literatury i teatru, od 1906 roku pracownika Biblioteki Zakładu Narodowego im. Ossolińskich we Lwowie ${ }^{56}$. Konrad Górski zwrócił uwagę na powiązanie wydania Bernackiego z dramatem i zasugerował: „Kto wie, czy ukazanie się tej edycji nie skłoniło Kasprowicza, aby wrócić do kontynuowania dzieła" ${ }^{57}$ po kilku latach. Anna Podstawka przypomniała zaś odautorskie stwierdzenie relacji między tekstem staropolskim i Kasprowiczowskim w dedykacji poetyckiej na egzemplarzu Marchołta, ofiarowanym Bernackiemu: „Niewiele wziął mój Marchołt z pana Bakałarza / z Koszyczek. [...] jak Marchołt ów prawdziwy, gębę niewypraną / Posiada i mój pupil. I w tym całe sedno / Krewieństwa"s8. Warto jednak upomnieć się o większe docenienie w interpretacjach owego kontekstu staropolskiego, niewyczerpującego się zresztą w tekście Jana z Koszyczek, z którego modernista „niewiele wziął”.

Obcowanie z tym utworem nie musiało się szczególnie zintensyfikować w lekturach Kasprowicza dopiero po wydaniu Bernackiego w 1913 roku. Ludwik Bernacki, wydawca Dziet poetyckich Kasprowicza w 1912 roku, nad staropolskim dziełem o Marchołcie pracował intensywnie, po wcześniejszych przygotowaniach, od 1910 roku, a bliskim znajomym Kasprowicza był przynajmniej od $1902^{59}$. Krystyna Korzon zauważyła:

istniało między Bernackim a Kasprowiczem kilka punktów stycznych. Jednym z nich stała się fikcyjna postać Marchołta, której rubaszny biologizm i filozoficzna niezależność od konwencji otaczającego świata współgrały z klimatem panującym w kasprowiczowskich kręgach. Postać ta zafascynowała tak Kasprowicza, jak i Bernackiego, stając się nieuchwytną spójnią między nimi. [...] prolog - napisał Kasprowicz we

Kasprowicz w osiemdziesiąta rocznicę śmierci, red. M. Sosnowski, G. Igliński, Polskie Bractwo Kawalerów Gutenberga, Warszawa 2006, s. 157-170; tenże, W zgodzie z bytem i przeznaczeniem. Rozważania o osobowości Jana Kasprowicza. Psychologiczny portret twórcy, Polskie Bractwo Kawalerów Gutenberga, Warszawa 2010, s. 285-289.

${ }^{56}$ Rozmowy ktore myat Krol Salomon madry z Marcholtem grubym a sprosnym..., wyd. L. Bernacki, nakładem Wydawcy, Haarlem 1913. Por. K. Korzon, Ludwik Bernacki, Bibliolog i edytor, Zakład Narodowy im. Ossolińskich, Wrocław 1974, s. 32-63.

${ }^{57}$ K. Górski, ,,Marcholt”, w: tenże, Jan Kasprowicz. Studia, Państwowy Instytut Wydawniczy, Warszawa 1977, s. 81. Por. J. Nowosielska-Koźlińska, Teatr poety. Sztuka dramatopisarska Jana Kasprowicza, [s.n.], Inowrocław 2009, s. 153-155.

${ }^{58}$ Cyt. za: A. Podstawka, dz. cyt., s. 355.

${ }^{59}$ Por. K. Korzon, dz. cyt., s. 58, 69. 
wrześniu 1903 r., tj. w latach szerokich towarzyskich spotkań, których i Bernacki bywał uczestnikiem ${ }^{60}$.

Staropolski Marchołt był najprawdopodobniej znany Kasprowiczowi, gdy pracował nad koncepcją i tekstem dramatu, tak zasadniczego dla poety na etapie syntezy światopoglądu. Z punktu widzenia potrzeby badań nie ma znaczenia, czy Marchołt Kasprowicza powstawał jako potwierdzenie czy zaprzeczenie kreacji i wizji staropolskiej; faktem jest, że powstawał w jej świadomości i w dialogu $\mathrm{z}$ nią, i dialog ten warto badać.

Znajomość z Bernackim łączy się też z innymi aspektami dialogu tego tekstu młodopolskiego $\mathrm{z}$ tekstami staropolskimi. Zwracano uwagę na powinowactwo treściowe i tekstowe Marchołta Kasprowicza z komedią Z chtopa król Piotra Baryki z 1637 roku $^{61}$. I ten utwór staropolski znalazł się na biurku Bernackiego-edytora, który jeszcze na seminarium Romana Pilata w czasie studiów zaczął, kontynuowane przez lata, opracowanie tematu Motyw ,z chtopa król”, po czym za radą Aleksandra Brücknera skoncentrował się na tekście Baryki i przygotował go, polecony przez Brücknera redaktorom serii, do wydania w „Bibliotece Pisarzów Polskich" ${ }^{62}$ krakowskiej Akademii Umiejętności w 1904 roku $^{63}$.

To wciąż nie koniec powiązań dramatu Kasprowicza z tekstami staropolskimi. Jak zauważono, w pierwodruku fragmentu Narodziny Marcholta w „Chimerze” w 1907 roku Kasprowicz opatrzył tekst mottem z Komedii rybałtowskiej nowej z 1615 roku $^{64}$. Utwór ten został wydany w 1902 roku w warszawskiej „Bibliotece Zapomnianych Poetów i Prozaików Polskich XVI-XVIII w." ${ }^{55}$ przez Teodora Wierzbowskiego, wybitnego znawcę archiwaliów i autora bibliografii druków XV-XVI wieku, ważnego konsultanta naukowego Ludwika Bernackiego na etapie przygotowywania edycji komedii Baryki. Dodajmy, że także sugerowana niekiedy inspiracja Kasprowicza średniowieczną Rozmowa Mistrza Polikarpa ze Śmiercią ${ }^{66}$ da się powiązać z lekturą konkretnej edycji - wydał ją w 1903 roku w „Materiałach i Pracach Komisji Językowej Akademii Umiejętności w Krakowie"67 Jan Rozwa-

\footnotetext{
${ }^{60}$ Tamże, s. 71-72.

${ }^{61}$ Por. A. Podstawka, dz. cyt., s. 398.

${ }^{62}$ P. Baryka, Z chłopa król. Komedya dworska (1637), wyd. L. Bernacki, Akademia Umiejętności, Kraków 1904, „Biblioteka Pisarzów Polskich”, nr 49.

${ }^{63}$ Por. K. Korzon, dz. cyt., s. 19-20, 26-28, 35-38.

${ }^{64}$ Por. A. Podstawka, dz. cyt., s. 356.

${ }^{65}$ Komedya rybaltowska z r. 1615 i Soltys z Klecha z r. 1616, wyd. T. Wierzbowski, Kasa im. J. Mianowskiego, Warszawa 1902, „Biblioteka Zapomnianych Poetów i Prozaików Polskich XVI-XVIII w.”, z. 18.

${ }^{66}$ M. Podraza-Kwiatkowska, Literatura Młodej Polski, Wydawnictwo Naukowe PWN, Warszawa 1992, s. 168.

${ }^{67}$ De morte prologus i żale konającego, wyd. J. Rozwadowski, AU, Kraków 1903, „Materiały i Prace Komisji Językowej Akademii Umiejętności w Krakowie”, t. I.
} 
dowski, członek akademii, późniejszy jej prezes i współpracownik w niej i Kasprowicza, i Bernackiego.

Jan Kasprowicz, sam zresztą gromadzący od 1900 roku księgozbiór, w skład którego wchodziły liczne stare druki, dzięki intensywnemu na przełomie wieków rozwojowi edytorstwa dzieł dawnych miał od początku prac nad Marchołtem łatwy dostęp do tekstów staropolskich i naukowej refleksji nad nimi. Fakt to warty pełniejszego wykorzystania w badawczej refleksji nad światopoglądem i założeniami artystycznymi poety. Jej wyniki mogłyby na przykład rzucić nowe światło na znane, zdawałoby się, zagadnienie Kasprowiczowskiego klasycyzmu.

Snopem światła w zupełnym mroku może być natomiast dołączenie kontekstu staropolskiego do interpretacji utworu Wizerunek człowieka w r. 1906 w Polsce poczciwego i tym samym do analizy myśli Grzegorza Glassa ${ }^{68}$, pisarza i publicysty, działacza społecznego związanego z radykalną inteligencją. Wydana w Krakowie w 1908 roku jego wielostylowa powieść, łącząca zjadliwą satyrę o celach publicystycznych z neoromantycznym patosem, prorewolucyjny pamflet na środowiska burżuazji i endecji, a także młodopolskich artystów ${ }^{69}$, nosi podtytuł $\mathrm{Pa}$ miętnik śp. Wiesława Wrony, przemystowca, kupca, obywatela, wyborcy (z mistyfikacyjnym dopiskiem z rękopisu podat do druku G. Glass), który jakby odsuwa z pierwszego planu skojarzenie z twórczością Mikołaja Reja, oczywiste przecież dla głównego tytułu, a niewykorzystywane w ogóle w analizie tekstu i interpretacji jego wymowy. Nie dziwi to zresztą, zważywszy odległość formalną i tematyczną tej powieści modernistycznej od dzieł pana z Nagłowic, przede wszystkim przywoływanych tu ewidentnie utworów Żywot czlowieka poczciwego i Wizerunk własny żywota człowieka poczciwego, w którym jako we źwierciedle snadnie każdy swe sprawy oględać może, zebrany i z filozofów, i z różnych obyczajów świata tego. Tekst powieści Glassa sugestii tytułowej w ogóle nie rozwija, trudno więc podążyć drogą tego skojarzenia. Wskazówka tkwi właśnie w ówczesnej historii literatury i dziejach edytorstwa dzieł staropolskich. W 1905 i 1906 roku obchodzono, zapowiadany i przygotowywany już sporo wcześniej, jubileusz czterechsetlecia urodzin Nagłowiczanina, z apogeum w postaci krakowskiego zjazdu historycznoliterackiego im. Mikołaja Reja; pojawiły się wówczas liczne rozprawy, artykuły, teksty literackie i przedstawienia dotyczące Reja $^{70}$.Zjubileuszem wiązały się także liczne projekty edytorskie ${ }^{71}$, przedsiębrane także już kilka lat wcześniej:

${ }^{68}$ G. Glass, Wizerunek człowieka w r. 1906 w Polsce poczciwego. Pamiętnik śp. Wiesława Wrony, przemystowca, kupca, obywatela, wyborcy, [s.n.], Kraków 1908.

${ }^{69}$ Por. M.J. Olszewska, Grzegorza Glassa wizja rewolucji. Rozważania w kontekście ,Wizerunku człowieka w r. 1906 w Polsce poczciwego”, w: taż, W poszukiwaniu sensu. Szkice o literaturze polskiej XIX i XX wieku, Wydział Polonistyki UW, Warszawa 2005, s. 305-322.

70 Por. J. Okoń, Wokót jubileuszy Mikołaja Reja (Obchody 400. rocznicy urodzin w Akademii Umiejętności w Krakowie), „Ruch Literacki” 2004, z. 2, s. 155-171; W. Hahn, Bibliografia o Mikołaju Reju za rok 1905, „Pamiętnik Literacki” 1905, s. 569-578.

${ }^{71}$ Por. M.M. Kacprzak, Edycje literatury staropolskiej..., s. 80-86. 
Samuel Adalberg planował przed rocznicą zakończyć, podjęte w 1897 roku, krytyczne wydanie Zwierciadła, w skład którego wchodzi Żywot człowieka poczciwe$\mathrm{go}^{72}$; rocznicę zapowiadała opracowana przez Józefa Kallenbacha edycja Zwierciadła z 1903 roku (2 pierwsze tomy to Żywot człowieka poczciwego) w ,Zbiorze Pisarzy Polskich”, podserii „Biblioteki Dzieł Wyborowych”73; w 1905 roku Wiktor Wittyg „Dla uczczenia czterechsetnej rocznicy urodzin autora wydał w podobiźnie" Figliki ${ }^{74}$; wreszcie 1905 rok przyniósł pełne wydanie Zwierciadła z $\dot{Z} y$ wotem człowieka poczciwego, przygotowane przez Jana Czubka i Jana Łosia, przedsięwzięte przez Akademię Umiejętności w Krakowie dla uhonorowania pisarza „trwałym pomnikiem jego niespożytych zasług około języka i literatury

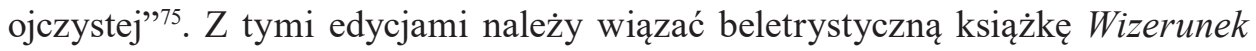
Mikołaja Reja z Nagłowic z 1905 roku $^{76}$ Adolfa Nowaczyńskiego (który zresztą wystawił w 1905 i wydał w 1906 roku sztukę Jegomość pan Rej w Babinie. Świecka krotofila $w$ trzech sprawach na czterechsetny anniwersarz napisana ${ }^{77}$ ). Powieść, przedstawiająca w staropolskiej stylizacji życie i twórczość pisarza, niewątpliwie opiera się na szesnastowiecznej biografii sygnowanej nazwiskiem Andrzeja Trzecieskiego młodszego ${ }^{78}$, zamieszczonej w staropolskim wydaniu Zwierciadła i z nim przedrukowywanej w dziewiętnastowiecznych edycjach. Omawia szeroko także utwór Reja Wizerunk własny żywota człowieka poczciwego z 1558 roku, przypomniany zresztą w XIX stuleciu w bardzo starannej edycji naukowej, wydawanej przez Stanisława Ptaszyckiego w latach 1881-188979. Zarówno obydwie książki Nowaczyńskiego, jak i edycje Zwierciadła i Figlików Reja z 1905 roku mają kształt typograficzny oparty (w różnym stopniu) na stylizacji na wydanie starodruczne. Tym bardziej pewne jest powiązanie Wizerunku człowieka w r. 1906 w Polsce poczciwego Glassa z tymi edycjami, że jego okładka ozdobiona jest ryciną (nie wskazano jej autorstwa) ewidentnie stylizowaną na frontyspis starodruku, z portretem bohatera i sfingowanego autora tekstu, przypominającym słynne portrety staropolskie Reja z pierwodruków jego dzieł, prze-

${ }^{72}$ M. Rej, Zwierciadto podtug wydania pierwszego z roku 1567/8, wyd. S. Adalberg, z. 1, E. Wende, Kraków 1897.

${ }^{73}$ M. Rej, t. 1-2 Żywot człowieka poczciwego, t. 3-4 Spólne narzekanie na niedbałość naszę, A.T. Jezierski, Warszawa 1903, „Biblioteka Dzieł Wyborowych”, nr 263, 268, 273, 308, „Zbiór Pisarzy Polskich” wyd. pod kier. J. Kallenbacha.

${ }^{74}$ M. Rej, Figliki, wyd. W. Wittyg, Drukarnia UJ, Kraków 1905.

${ }^{75}$ M. Rej, Zwyerciádło, [red. J. Czubek, J. Łoś, AU, Kraków 1905], s. 1. nlb.

${ }^{76}$ A. Nowaczyński, Wizerunek Mikołaja Reja z Nagłowic, J. Fiszer, Warszawa 1905.

77 Tenże, Jegomość pan Rej w Babinie. Świecka krotofila w trzech sprawach na czterechsetny anniwersarz napisana, W. Wiediger, Kraków 1906.

${ }^{78}$ Por. M. Piotrowska, ,,Wizerunek Mikołaja Reja z Nagłowic” Adolfa Nowaczyńskiego-źródta kreacji postaci, „Acta Universitatis Lodziensis. Folia Litteraria Polonica” 2003, nr 6, s. 219-227.

${ }^{79}$ M. Rej, Wizerunk własny żywota człowieka poczciwego Podług edycyi z r. 1560, wyd. S. Ptaszycki, Księgarnia Polska, Petersburg-Warszawa 1881-1889. 
drukowywane w edycjach dziewiętnastowiecznych. Nie miejsce tu na wnikliwą analizę i interpretację powieści Glassa w odniesieniu do Wizerunku własnego zywota czlowieka poczciwego i Żywota czlowieka poczciwego Reja, nie ma jednak wątpliwości, że zignorowanie w badaniu powiązania tych dzieł oznacza zaprzepaszczenie szansy na odczytanie części sensu, w sposób świadomy i celowy sugerowanego przez autora utworu modernistycznego.

Wspomniane stylizacje typograficzne książek z przełomu wieków zwracają uwagę na jeszcze jeden aspekt znaczenia edycji dzieł staropolskich dla Młodej Polski. Andrzej Z. Makowiecki zauważył:

Literatura i sztuki plastyczne w dobie Młodej Polski spotykały się na [...] wielce naturalnej płaszczyźnie kontaktu. Zdobnictwo książki i czasopisma, artystyczna typografia i rozmaite formy grafiki na użytek literatury stały się przedmiotem zainteresowania artystów w stopniu nie spotykanym $w$ innych epokach. [...] rzadko udaje się osiągnąc tak wysoki poziom zdobnictwa książkowego i sztuki drukarskiej, jak na przełomie wieków. Potrzeba odnowienia sztuki edytorskiej brała się w okresie Młodej Polski z przeświadczenia o konieczności syntetyzowania wrażeń estetycznych, w którym jednym z narzucających się rozwiązań było stworzenie z czasopisma lub książki ,pięknego" przedmiotu ${ }^{80}$.

Dziewiętnastowieczne edytorstwo literatury epok dawnych podążało wieloma ścieżkami rozwoju; wśród nich ważną rolę odegrało tworzenie różnego rodzaju fototypicznych podobizn starych druków - stron tytułowych, rycin i całych książek. W kulturze edytorskiej całego XIX stulecia przypisywano faksymiliom dużą rolę, zarówno w konserwacji zabytków, uzupełnianiu księgozbiorów, jak i budzeniu patriotycznego zainteresowania przeszłością oraz umożliwianiu rzetelnych badań nad dawnym polskim językiem i literaturą ${ }^{81}$. Pozwalały one zetknąć się z estetyką książki staropolskiej i czytelnikom, i pracownikom książki. Na przełomie XIX i XX w. zainteresowanie takimi pracami wzmocniły idee syntezy sztuk i estetyzacji codzienności; i tak estetyka typografii staropolskiej stała się tworzywem estetyki młodopolskiej w stylizacjach, które ukształtowały książkowe edycje literatury staropolskiej oraz książki związane z kulturą dawną. Profesjonalnych badań wymaga poszukiwanie odpowiedzi na pytanie o wpływ tej estetyki na typografię książek młodopolskich oraz na sztukę młodopolską w ogóle, także w miejscach, gdzie powiązania tematycznego ze staropolszczyzną wskazać nie sposób.

${ }^{80}$ A.Z. Makowiecki, Wzajemne zwiazki literatury i sztuk pięknych, w: J. Kulczycka-Saloni, I. Maciejewska, A.Z. Makowiecki, R. Taborski, Młoda Polska, Wydawnictwo Naukowe PWN, Warszawa 1992, s. 209-210.

${ }^{81}$ Por. J. Sowiński, Między oryginałem, kopia a falsyfikatem. Polskie edycje faksymilowe, Wydawnictwo Naukowe Uniwersytetu Pedagogicznego, Kraków 2009, s. 18-22. 
Przykład omawianego zjawiska stanowić może ciesząca się dużym uznaniem plastyka książkowa Jana Bukowskiego, ilustratora, malarza, rysownika i witrażysty, od 1904 roku kierownika artystycznego Drukarni Uniwersytetu Jagiellońskiego ${ }^{82}$, którego działalność nie sprowadzała się do opatrywania książek ilustracjami, ale, podobnie jak w przypadku Wyspiańskiego, często obejmowała projekt graficzny całości edycji ${ }^{83}$. Przykład jego pracy to wspomniane wydanie bibliofilskie Zwierciadła Reja z 1905 roku, które powstało z zamiarem zaprezentowania znawcom i szerokiemu gronu odbiorców nieprofesjonalnych zabytku piśmiennictwa i edytorstwa „w postaci nowożytnej, oddającej jednak stylowe właściwości XVI. stulecia”, tak że „książka zachowuje ile możności wszystkie cechy pierwodruku, od rycin i ozdób drukarskich aż do papieru i formatu; dopełnia całości okładka w stylu XVI w." ${ }^{" 4}$. W krótkim posłowiu, wskazując skrzętnie sprawców kształtu merytorycznego i technicznego edycji, oprócz Bukowskiego wymieniono między innymi także introligatora Roberta Jahodę, specjalizującego się w oprawach starodrucznych i bibliofilskich właściciela krakowskiej pracowni, w której artyści poszukiwali nowego stylu opraw ${ }^{85}$. Znamienne, że Bukowski obok edycji staropolskich - Bogurodzicy (Kraków 1910), opracowanej przez Władysława Bełzę Antologii polskiej stu poetów od średniowiecza do współczesności (w tym: Bogurodzica, Jan Kochanowski, Mikołaj Rej, Sebastian Fabian Klonowic, Mikołaj Sęp Szarzyński, Stanisław Grochowski, Szymon Szymonowic, Kasper Miaskowski, Szymon Zimorowic, Jan Andrzej Morsztyn, Wacław Potocki, Wespazjan Kochowski; Lwów 1906) - i związanych z kulturą staropolską - wspomnianego Wizerunku Mikołaja Reja z Nagłowic Nowaczyńskiego czy prac Kazimierza Chłędowskiego popularyzujących kulturę włoską i renesansową - projektował na przykład także wydania poezji Jana Wroczyńskiego (Lwów 1905), Ech leśnych Stefana Żeromskiego (Kraków 1905) czy wreszcie Legendy Młodej Polski Stanisława Brzozowskiego (wyd. 2, Lwów 1910).

Niniejszy szkic nie wyczerpuje, rzecz jasna, problematyki związanej z badaniami powiązań między dziewiętnastowiecznym edytorstwem dzieł staropolskich i światopoglądem polskiego modernizmu. Rekonesans ten stanowi zaproszenie do uwzględnienia $\mathrm{w}$ badaniach ważnego aspektu ówczesnego ruchu wydawniczego, a wynika z przekonania, że odpowiedź na pytanie o miejsce wydań literatury staropolskiej w życiu kulturalnym i literackim oraz profilu intelektualnym i artystycznym polskiego modernizmu może przybliżyć rozpoznanie jego swoistości na tle kultury europejskiej. Być może wprowadzanie przez edy-

${ }^{82}$ Por. Słownik pracowników książki polskiej, [red. I. Treichel], PWN, Warszawa-Łódź 1972, s. $100-101$.

${ }^{83}$ Por. A.Z. Makowiecki, Wzajemne zwiazki..., s. 211.

${ }^{84}$ M. Rej, Zwyerciádło, s. 1. nlb.

${ }^{85}$ Por. Stownik pracowników ksiązki..., s. 355. 
cje w obieg czytelniczy i świadomość społeczną staropolskich dzieł literackich i uobecnianie związanych z nimi tradycji czy mitów narodowych pozwoliło im stać się składnikami światopoglądu modernistycznego.

\section{Bibliografia}

Baryka Piotr, Z chłopa król. Komedya dworska (1637), wyd. Ludwik Bernacki, Akademia Umiejętności, Kraków 1904, „Biblioteka Pisarzów Polskich”, nr 49.

Berent Wacław, Źródła i ujścia nietzscheanizmu, „Chimera” 1905, t. IX, z. 25, s. 118-139.

Brandes Georg, Umysty współczesne. Portrety literackie XIX wieku, przeł. M. Posner-Garfein, t. 2, Redakcja „Głosu”, Warszawa 1894.

Bukowiński Władysław, Przegląd teatralny, „Prawda” 1907, nr 44, s. 521-522.

Burckhardt Jacob, Kultura odrodzenia we Włoszech, tłum. wg III wydania, popr. przez L.[udwiga]. Geigera, przez L.[udwikę] M.[ycielską], t. I, Spółka Wydawnicza Polska, Kraków 1895, t. II, Spółka Wydawnicza Polska, Kraków 1897.

Chlebowski Bronisław, Indywidualizm jako czynnik rozwoju artyzmu polskiego w wieku XVI, w: Prawda. Książka zbiorowa dla uczczenia dwudziestopięcioletniej działalności Aleksandra Świętochowskiego. 1870-1895, Księgarnia H. Altenberga - K. Grendyszyński, LwówPetersburg 1899, s. 80-93.

Chmielowski Piotr, Z czasów Odrodzenia (Jacob Burckhardt „Kultura Odrodzenia we Włoszech”), „Kurier Codzienny” 1897, nr 307, s. 2.

Cysewski Kazimierz, Między historia badań literackich a teoria literatury, Wydawnictwo Uniwersytetu Warmińsko-Mazurskiego, Olsztyn 2002.

Cysewski Kazimierz, Z zagadnień literaturoznawstwa polskiego doby pozytywizmu 1860-1914, Wyższa Szkoła Pedagogiczna, Słupsk 1986.

Czachowski Kazimierz, Obraz współczesnej literatury polskiej, t. II, Państwowe Wydawnictwo Książek Szkolnych, Lwów 1934.

Daszyńska Zofia, Nietzsche - Zarathustra. Studium literackie, Drukarnia Narodowa F.K. Pobudkiewicza, Kraków 1896.

De morte prologus $i$ żale konającego, wyd. Jan Rozwadowski, Akademia Umiejętności, Kraków 1903, „Materiały i Prace Komisji Językowej Akademii Umiejętności w Krakowie”, t. I.

Fidelus Michał, O wydawnictwach staropolskich tekstów literackich przed rokiem 1918, „Ruch Literacki" 1971, z. 1, s. 45-50.

Galli Anonymi chronicon, wyd. Stanisław Kętrzyński, Ludwik Finkel, Lwów 1899, „Fontes rerum Polonicarum in usum scholarum", t. 1.

Geiger Ludwig, Odrodzenie i humanizm we Włoszech i Niemczech, przeł. S. Mieczyński, druk. S. Lewentala, Warszawa 1896.

Glass Grzegorz, Wizerunek człowieka w r. 1906 w Polsce poczciwego. Pamiętnik śp. Wiesława Wrony, przemysłowca, kupca, obywatela, wyborcy, [s.n.], Kraków 1908.

Górski Konrad, Jan Kasprowicz. Studia, PIW, Warszawa 1977.

Górski Konrad, Rozważania teoretyczne. Literatura, muzyka, teatr, Redakcja Wydawnictw KUL, Lublin 1984.

Hahn Wiktor, Bibliografia o Mikołaju Reju za rok 1905, „Pamiętnik Literacki” 1905, s. 569-578. 
Kacprzak Marta M., Edycje literatury staropolskiej w życiu Polaków XIX w. na przykładzie wydań „Zwierciadta” Mikołaja Reja, w: Na co dzień i od święta. Książka w życiu Polaków w XIX-XXI wieku, red. nauk. A. Chamera-Nowak, D. Jarosz, Oficyna Wydawnicza ASPRA-JR, Warszawa 2015, s. 71-90.

Kasprowicz Jan, Marchołt gruby a sprośny. Jego narodzin, życia i śmierci misterium tragikomiczne, Gubrynowicz, Lwów 1920.

Kętrzyński Stanisław, Gall-Anonim i jego kronika, Akademia Umiejętności, Kraków 1898.

Komedya rybattowska z r. 1615 i Soltys z Klecha z r. 1616, wyd. Teodor Wierzbowski, Kasa im. J. Mianowskiego, Warszawa 1902, „Biblioteka Zapomnianych Poetów i Prozaików Polskich XVI-XVIII w.", z. 18.

Kopij Marta, Friedrich Nietzsche w literaturze i publicystyce polskiej lat 1883-1918. Struktura recepcji, Wydawnictwo Poznańskie, Poznań 2005.

Korzon Krystyna, Ludwik Bernacki, Bibliolog i edytor, Zakład Narodowy im. Ossolińskich, Wrocław 1974.

Kowalczuk Urszula, Powinność i przygoda. Pisarze polscy drugiej połowy XIX wieku wobec kultury renesansu, Wydział Polonistyki UW, Warszawa 2011.

Kowalczuk Urszula, 1884 - jubileuszowa „renowacja” Kochanowskiego, w: Upominki od narodu. Jubileusze, rocznice, obchody pisarzy, red. T. Budrewicz, P. Bukowski, R. Stachura-Lupa, Muzeum Marii Konopnickiej, Żarnowiec 2010, s. 103-119.

Kulczycka-Saloni Janina, Maciejewska Irena, Makowiecki Andrzej Z., Taborski Roman, Młoda Polska, Wydawnictwo Naukowe PWN, Warszawa 1992.

Lange Antoni, J. Burckhardt „Kultura Odrodzenia we Włoszech”, „Ateneum” 1896, t. I, z. 3, s. $587-592$.

Lewański Julian, „Odprawa posłów greckich” w teatrach XIX i XX wieku, w: Jan Kochanowski $i$ epoka renesansu. W 450 rocznice urodzin poety 1530-1980, red. T. Michałowska, PWN, Warszawa 1984, s. 381-392.

Makowiecki Andrzej Z., Młoda Polska wobec tradycji czarnoleskiej, w: Jan Kochanowski 15841984. Epoka - Twórczość - Recepcja, red. J. Pelc, P. Buchwald-Pelcowa, B. Otwinowska, t. 2 , Wydawnictwo Lubelskie, Lublin 1989, s. 331-342.

Makowiecki Andrzej Z., Wzajemne związki literatury i sztuk pięknych, w: J. Kulczycka-Saloni, I. Maciejewska, A.Z. Makowiecki, R. Taborski, Młoda Polska, Wydawnictwo Naukowe PWN, Warszawa 1992, s. 209-210.

Markiewicz Henryk, Polska nauka o literaturze. Zarys rozwoju, PWN, Warszawa 1981.

Matuszewski Ignacy, Wzniosłość u Słowackiego (Przyczynek do psychologii geniuszu poety), w: Słowacki Juliusz, Dzieła (wydanie ilustrowane), red. F. Hoesick i L. Méyet, t. I, „Wędrowiec", Warszawa 1903, s. V-XXIV.

Namerła Witold, Inscenizacje „Odprawy posłów greckich” 1870-1978, „Pamiętnik Teatralny” 1978, z. 3, s. 365-382.

Niewolak-Krzywda Anna, W kręgu rzeczy czarnoleskiej, Krajowa Agencja Wydawnicza, Rzeszów 1987.

Nowaczyński Adolf, Jegomość pan Rej w Babinie. Świecka krotofila w trzech sprawach na czterechsetny anniwersarz napisana, W. Wiediger, Kraków 1906.

Nowaczyński Adolf, Wizerunek Mikołaja Reja z Nagłowic, J. Fiszer, Warszawa 1905.

Nowosielska-Koźlińska Joanna, Teatr poety. Sztuka dramatopisarska Jana Kasprowicza, [s.n.], Inowrocław 2009. 
Okoń Jan, Wokół jubileuszy Mikołaja Reja (Obchody 400. rocznicy urodzin w Akademii Umiejętności w Krakowie), „Ruch Literacki” 2004, z. 2, s. 155-171.

Olszewska Maria Jolanta, W poszukiwaniu sensu. Szkice o literaturze polskiej XIX i XX wieku, Wydział Polonistyki UW, Warszawa 2005.

Pamiętnik zjazdu historyczno-literackiego imienia Jana Kochanowskiego, „Archiwum do dziejów literatury i oświaty w Polsce, wydawane przez komisję do badań tego zakresu przez Wydział Filologiczny Akademii Umiejętności w Krakowie powołaną", t. V, Kraków 1886.

Piotrowska Małgorzata, ,Wizerunek Mikołaja Reja z Nagłowic” Adolfa Nowaczyńskiego - źródła kreacji postaci, „Acta Universitatis Lodziensis. Folia Litteraria Polonica” 2003, nr 6, s. 219-227.

Podraza-Kwiatkowska Maria, Literatura Młodej Polski, Wydawnictwo Naukowe PWN, Warszawa 1992.

Podstawka Anna, Świat, który się nie kończy. Człowiek i transcendencja w teatrze Jana Kasprowicza, Wydawnictwo KUL, Lublin 2014.

Pro memoria. Jan Kasprowicz w osiemdziesiątą rocznicę śmierci, red. M. Sosnowski, G. Igliński, Polskie Bractwo Kawalerów Gutenberga, Warszawa 2006.

Przewóska Maria, Fryderyk Nietzsche jako moralista i krytyk. Studium filozoficzne, H. Cohn, Warszawa 1894.

Przybyszewski Stanisław, Listy, t. II, „Parnas Polski”, Warszawa 1938.

Przybyszewski Stanisław, Moja autobiografia, „Wiadomości Literackie” 1928, nr 18, s. 2.

Przybyszewski Stanisław, Szlakiem duszy polskiej, Ostoja, Poznań 1917.

Rej Mikołaj, Figliki, wyd. Wiktor Wittyg, Drukarnia Uniwersytetu Jagiellońskiego, Kraków 1905.

Rej Mikołaj, Wizerunk własny żywota człowieka poczciwego Podług edycyi z r. 1560, wyd. Stanisław Ptaszycki, Księgarnia Polska, Petersburg-Warszawa 1881-1889.

Rej Mikołaj, Zwierciadło podtug wydania pierwszego z roku 1567/8, wyd. Samuel Adalberg, z. 1, E. Wende, Kraków 1897.

Rej Mikołaj, Zwyerciádto, [red. Jan Czubek, Jan Łoś, Akademia Umiejętności, Kraków 1905].

Rej Mikołaj, t. 1-2 Żywot człowieka poczciwego, t. 3-4 Spólne narzekanie na niedbałość naszę, A.T. Jezierski, Warszawa 1903, „Biblioteka Dzieł Wyborowych”, nr 263, 268, 273, 308, „Zbiór Pisarzy Polskich” wyd. pod kier. J. Kallenbacha.

Rozmowy ktore myat Krol Salomon madry z Marchottem grubym a sprosnym..., wyd. Ludwik Bernacki, nakładem Wydawcy, Haarlem 1913.

Słownik pracowników książki polskiej, [red. I. Treichel], PWN, Warszawa-Łódź 1972.

Sosnowski Mirosław, W zgodzie z bytem i przeznaczeniem. Rozważania o osobowości Jana Kasprowicza. Psychologiczny portret twórcy, Polskie Bractwo Kawalerów Gutenberga, Warszawa 2010.

Sowiński Janusz, Między oryginałem, kopiq a falsyfikatem. Polskie edycje faksymilowe, Wydawnictwo Naukowe Uniwersytetu Pedagogicznego, Kraków 2009.

Starnawski Jerzy, Kronika edytorstwa naukowego w Polsce, w: tenże, Praca wydawcy naukowego, wyd. 2 poszerz., Zakład Narodowy im. Ossolińskich, Wrocław 1992, s. 147-196.

Starnawski Jerzy, Refleksje rocznicowe. 1884-1930-1980/1984, w: Jan Kochanowski 1584-1984. Epoka - Twórczość - Recepcja, red. J. Pelc, P. Buchwald-Pelcowa, B. Otwinowska, t. 2, Wydawnictwo Lubelskie, Lublin 1989, s. 371-390.

Taine Hippolyte, Filozofia sztuki, przeł., przypisami i skorowidzem opatrzył A. Sygietyński, druk. S. Lewentala, Warszawa 1896.

Taine Hippolyte, Podróż po Włoszech, przeł. A. Sygietyński, wyd. nowe, opatrzone objaśnieniami, Księgarnia Powszechna, Warszawa 1908. 
Vaihinger Hans, Filozofia Nietzschego, przeł. K. Twardowski, H. Altenberg - E. Wende, LwówWarszawa 1904.

Weiss Tomasz, Fryderyk Nietzsche w piśmiennictwie polskim lat 1890-1914, PWN, Warszawa 1961.

Wojciechowski Tadeusz, Szkice historyczne jedynastego wieku, Akademia Umiejętności, Kraków 1904.

Zapolska Gabriela, Listy, oprac. S. Linowska, t. I, Państwowy Instytut Wydawniczy, Warszawa 1970.

Zawodziński Karol Wiktor, Czterdzieści lat z Kochanowskim, czyli metamorfozy pojęcia poezji, „Twórczość” 1946, z. 5, s. 58-78.

Marta M. Kacprzak

\section{Nineteenth-century editions of Old Polish literature and the worldview of Polish modernism. A reconnaissance}

\section{(Summary)}

1890-1918 was a time of intensive development of editorial works on literary texts, continuing workshop and ideological explorations in publishing work that started in the early nineteenth century. Chief editorial tasks and objectives were defined, principles were developed and a growing number of new editions of Old Polish works were made available. Did introducing them into readership and social awareness contributed to changing the outlook of the modernist era? Did historical phenomena, national traditions and myths found in traditional Polish literary works became a component of the modernist worldview thanks to those editions? The article is an invitation to examine an important aspect of publishing movement of 1890-1918, arguing that finding an answer to the question about the place of editions of Old Polish literature in the cultural and literary life as well as intellectual and artistic profile of Polish modernism may contribute to its specificity being recognised within European culture.

Słowa kluczowe: literatura staropolska - recepcja; edytorstwo - historia; historia książki - XIX wiek

Keywords: Old Polish literature - reception; editing - history; story of the book - nineteenth century 